\title{
Robotics and inclusion of students with disabilities in special education
}

\author{
Robótica e inclusão de estudantes com deficiência na educação especial \\ La robótica y la inclusión de alumnos con discapacidad en la educación especial
}

Received: 07/14/2021 | Reviewed: 07/19/2021 | Accept: 07/20/2021 | Published: 07/23/2021

Christine Syriopoulou-Delli

ORCID: https://orcid.org/0000-0003-1490-8899

University of Macedonia, Greece E-mail: csyriop@gmail.com

Eleni Gkiolnta

ORCID: https://orcid.org/0000-0003-4531-9667

University of Macedonia, Greece E-mail: egkiolnta@uom.edu.gr

\begin{abstract}
The concept of inclusion and inclusive education for children and adolescents with disabilities has been a topic of research for many countries over the last decades. Among the different methods and practices that have been implemented for interventions, the use of novel technologies and especially educational robotics has been proven to be a valuable tool. In this study, the authors attempted to define and examine those skills that are acquired through robotic interventions, and also the way they are associated with successful inclusion. The areas of social, cognitive, and functional skills of children and adolescents with disabilities were examined and their enhancement through robotics was assessed. For the purposes of this review, the authors searched Research Gate, Google Scholar, Scopus, PubMed, and Science Direct and identified relevant research papers. After the application of eligibility criteria, 12 research papers were considered suitable for analysis. The analysis of results indicates that most children and adolescents with disabilities that participated in interventions with robots managed to develop their social, cognitive, and functional skills and in some cases, their inclusion in educational settings was facilitated. The findings of this review support the need for implementation of these newly introduced practices and also some implications are discussed.
\end{abstract}

Keywords: Robotics; Special education; Inclusion; Disabilities; Educational robotics.

\section{Resumo}

O conceito de inclusão e educação inclusiva para crianças e adolescentes com deficiência tem sido um tema de pesquisa em muitos países nas últimas décadas. Entre os diferentes métodos e práticas que têm sido implementados para intervenções, o uso de novas tecnologias e especialmente a robótica educacional tem sido comprovadamente uma ferramenta valiosa. Neste estudo, os autores tentaram definir e examinar aquelas habilidades que são adquiridas através de intervenções robóticas, e também a forma como elas são associadas à inclusão bem sucedida. As áreas de habilidades sociais, cognitivas e funcionais de crianças e adolescentes com deficiências foram examinadas e seu aprimoramento através da robótica foi avaliado. Para os fins desta revisão, os autores pesquisaram o Research Gate, Google Scholar, Scopus, PubMed e Science Direct e identificaram trabalhos de pesquisa relevantes. Após a aplicação dos critérios de elegibilidade, 12 artigos de pesquisa foram considerados adequados para análise. A análise dos resultados indica que a maioria das crianças e adolescentes com deficiência que participaram de intervenções com robôs conseguiu desenvolver suas habilidades sociais, cognitivas e funcionais e, em alguns casos, sua inclusão em ambientes educacionais foi facilitada. Os resultados desta análise apóiam a necessidade da implementação destas práticas recentemente introduzidas e também algumas implicações são discutidas.

Palavras-chave: Robótica; Educação especial; Inclusão; Deficiência; Robótica educacional.

\section{Resumen}

El concepto de inclusión y educación inclusiva para niños y adolescentes con discapacidades ha sido un tema de investigación para muchos países en las últimas décadas. Entre los diferentes métodos y prácticas que se han implementado para las intervenciones, el uso de tecnologías novedosas y especialmente la robótica educativa ha demostrado ser una herramienta valiosa. En este estudio, los autores trataron de definir y examinar las habilidades que se adquieren a través de las intervenciones robóticas, y también la forma en que se asocian con la inclusión exitosa. Se examinaron las áreas de habilidades sociales, cognitivas y funcionales de los niños y adolescentes con discapacidad y se evaluó su mejora a través de la robótica. Para realizar esta revisión, los autores realizaron búsquedas en Research Gate, Google Scholar, Scopus, PubMed y Science Direct e identificaron los trabajos de investigación pertinentes. Tras la aplicación de los criterios de elegibilidad, se consideraron aptos para el análisis 12 trabajos de investigación. El análisis de los resultados indica que la mayoría de los niños y adolescentes con discapacidad que participaron en 
intervenciones con robots lograron desarrollar sus habilidades sociales, cognitivas y funcionales y, en algunos casos, se facilitó su inclusión en entornos educativos. Los hallazgos de esta revisión apoyan la necesidad de implementar estas prácticas recientemente introducidas y también se discuten algunas implicaciones.

Palabras clave: Robótica; Educación especial; Inclusión; Discapacidad; Robótica educativa.

\section{Introduction}

Children and adolescents with disabilities face many obstacles impeding their inclusion in the educational system, a condition that gives rise to many restrictions in the course of their lives (Alston \& Hampton, 2000). Limitations like the insufficient training of educators regarding inclusive education, the lack of proper material and technical infrastructure, the restricted access to relevant programs, and the absence of support coming from the children's parents are some of the challenges that they usually encounter.

The Greek Legislation is supporting the "one school for all" concept since the year 2000, which is referring to the idea of inclusion of people with special educational needs in the educational system (Law 2817/2000). Also, the right to equal opportunities for students with different types of disabilities in every aspect of their lives is being promoted, and more specifically in the areas of education, vocational training/rehabilitation, and social life. With the establishment of a more recent law (Law 3699/2008) the need for educational and social inclusion of people with special educational needs and/or disabilities has been acknowledged, and also the right of people with autism and other developmental disabilities to participate in the educational process.

At this time, a plethora of research that supports the establishment of inclusive education and the factors that affect its implementation is available (Rodriguez \& Garro-Gil, 2015; Francisco et al., 2020). Some of these factors are the design and the employment of individualized intervention programs, the absence of most types of restrictions in the child's environment, and the access to the general curriculum (Francisco et al., 2020).

Besides having more "traditional" educational methods that have been adopted until now, the introduction of novel technologies in the school environment has been a topic of interest for many researchers and a reference point for teachers and educators of all grades. It has been found that their use can offer alternative ways of presenting teaching subjects and learning, thus contributing to the inclusion of students with disabilities and/or special educational needs. In addition, the occurrence of multisensory stimuli that accompanies their use is considered to be suitable for students with different learning profiles (Barrow et al., 2009).

Educational robotics constitutes a branch of novel technologies in education that is very widespread and involves the use of robotic tools in order to support it (Bargagna et al., 2019; Leroux, 1999). It is based on the "learning by doing" model, which provides a student with the opportunity to acquire knowledge through a course of actions. When using robotics, a student must think before taking action, therefore logical thinking and organizational skills are being used (Businaro et al. 2014). Additionally, it is worthwhile noting that robotics can promote collaborative learning through play (Johnson \& Johnson, 1994). According to other researchers, a benefit that derives from using robots is the development of higher-order cognitive skills, and especially of those skills that are related to problem-solving (Diamond, 2013).

Educational robotics tools, which can also be addressed as "robotic partners", are designed with the ability to adapt in different contexts depending on the circumstances. This fact constitutes an important factor that makes robotic tools effective mediators for the inclusion of children with disabilities in educational programs (Bargagna et al., 2019). Also, another important factor that supports this claim is the fact that educational robotics can promote learning through collaborative play with peers (Johnson \& Johnson, 1994).

In this literature review, the authors are going to analyze the effectiveness of educational robotics in enhancing the social, cognitive, and functional skills of children and adolescents with disabilities and its contribution to their successful 
inclusion in educational and social environments. Moreover, those factors that can make the application of robotics in the classroom feasible are going to be discussed, as well as some impediments that can prevent it. In the end, the authors will examine some parameters that link robotics to inclusive education.

\section{Methodology}

The methodology of this review was conducted by two researchers and it was based on the study "Five steps to conducting a systematic review" by Khan et al. (2003). The first step was to form the research questions of the review and those questions are presented below. Secondly, the authors conducted a search on prominent research databases, which were Research Gate, Google Scholar, Scopus, PubMed, and Science Direct. The keywords used were "robotics", "inclusion”, "special education", and "disability" combined. Only studies written in English that were published between 2015-2020 were included. The third step was to set the eligibility criteria for the research papers that were found on the databases mentioned above and they are discussed later on. The fourth step of the review was a summary presentation of the selected studies' data. These data are presented in the "Results" section. The final step of the study was the analysis of the obtained data and the provision of answers regarding the research questions.

\subsection{Aim and research questions}

This literature review aimed towards evaluating the effectiveness of educational robots as mediators for the successful inclusion of children with disabilities. It is, therefore, going to be analyzed whether robotic tools can enhance those skills that can contribute towards establishing educational and social inclusion. The following research questions were addressed:

$>$ Can educational robotics enhance the social skills of children with disabilities?

$>$ Can educational robotics enhance the cognitive skills of children with disabilities?

$>$ Among those skills that can be acquired using robotics and may facilitate inclusion, which are those that concern researchers the most?

$>$ Can educational robotics promote the successful inclusion of children with disabilities?

\subsection{Eligibility criteria}

Eligibility criteria are regarding all those factors that are being taken into account in order to include a study for analysis in a literature review. In this review, only studies that were published between 2015-2020 and were concerning the effectiveness of using robotic tools for enhancing skills that facilitate the inclusion of children with disabilities were included. Each study should be a case study, an experiment, or include some type of intervention. That being said, in order for a paper to be eligible for analysis, it should be a primary research article. Another important factor that was taken into consideration by the authors was the reference to a robotic tool's name and its characteristics.

Research articles that didn't include any data and implemented mainly theoretical approaches were not included in this literature review. Furthermore, papers that didn't include at least a small group of children with disabilities and those who had samples consisting solely of adults were rejected. Another reason for rejection was the lack of reference to the participants' age.

\subsection{Final selection of articles}

258 records were identified through database searching. 208 studies were left after removing duplicates and after the first screening, 105 were rejected. That means that 103 papers were left, and 67 of them were examined with eligibility and exclusion criteria. Finally, 55 research papers were rejected and the authors identified 12 articles for inclusion in the literature 
review.

Table 1. Presentation of research articles that were analyzed and general information.

\begin{tabular}{|c|c|c|c|c|c|c|c|}
\hline Research Team & $\begin{array}{l}\text { Type of } \\
\text { disability }\end{array}$ & $\begin{array}{l}\text { Number of } \\
\text { participants } \\
\text { (children/adole } \\
\text { scents with } \\
\text { disabilities) }\end{array}$ & $\begin{array}{c}\text { Participants' } \\
\text { age } \\
\text { (children/adole } \\
\text { scents) }\end{array}$ & $\begin{array}{l}\text { Name of } \\
\text { the robot }\end{array}$ & Setting & Aims & Results \\
\hline Lee et al. (2015) & $\begin{array}{c}\text { ASD or } \\
\text { intellectual } \\
\text { disability and } \\
\text { speech-language } \\
\text { disorder }\end{array}$ & 4 & $4 ; 8$ years (mean) & iRobiQ & $\begin{array}{l}\text { Speech } \\
\text { therapy center } \\
\text { or } \\
\text { rehabilitation } \\
\text { center }\end{array}$ & $\begin{array}{l}\text { Replacement of } \\
\text { the therapist with } \\
\text { a robotic tool to } \\
\text { enhance } \\
\text { communication } \\
\text { (social skills) }\end{array}$ & $\begin{array}{c}\text { Positive results in } \\
\text { augmenting speech, } \\
\text { greater maintenance } \\
\text { of results after therapy } \\
\text { as compared to using } \\
\text { computers }\end{array}$ \\
\hline $\begin{array}{l}\text { Shamsuddin et } \\
\text { al. (2015) }\end{array}$ & ASD & 12 & $5-12$ years & NAO & $\begin{array}{l}\text { Special } \\
\text { education } \\
\text { school }\end{array}$ & $\begin{array}{l}\text { Enhancement of } \\
\text { communication } \\
\text { (social skills) }\end{array}$ & $\begin{array}{l}\text { Most participants had } \\
\text { positive interactions } \\
\text { with the robot and } \\
\text { exhibited fewer } \\
\text { autistic behaviors }\end{array}$ \\
\hline $\begin{array}{c}\text { Bonarini et al. } \\
\text { (2016) }\end{array}$ & $\begin{array}{c}\text { ASD/ Down } \\
\text { syndrome, } \\
\text { intellectual } \\
\text { disability, ASD, } \\
\text { Prader-Willy } \\
\text { syndrome, } \\
\text { psychosis }\end{array}$ & $3 / 8$ & $\begin{array}{c}3 \text { years } / 6-10 \\
\text { years }\end{array}$ & Teo & $\begin{array}{c}\text { Rehabilitation } \\
\text { center }\end{array}$ & $\begin{array}{l}\text { Enhancement of } \\
\text { social skills and } \\
\text { improvement of } \\
\text { functionality } \\
\text { (social and } \\
\text { functional skills) }\end{array}$ & $\begin{array}{l}\text { Heterogeneity of } \\
\text { results, improved } \\
\text { functionality and } \\
\text { emergence of social } \\
\text { behaviors with the } \\
\text { robotic partner, } \\
\text { manifestation of } \\
\text { emotions, and } \\
\text { enhanced play skills }\end{array}$ \\
\hline $\begin{array}{c}\text { Encarnação et } \\
\text { al. (2017) }\end{array}$ & $\begin{array}{c}\text { Motor } \\
\text { impairment and } \\
\text { speech-language } \\
\text { disorder }\end{array}$ & 9 & $3-6$ years & $\begin{array}{c}\text { LEGOC } \\
\text { Education } \\
\text { Mindstorm } \\
\text { s }\end{array}$ & $\begin{array}{c}\text { General } \\
\text { education } \\
\text { school }\end{array}$ & $\begin{array}{l}\text { Enhancement of } \\
\text { academic skills } \\
\text { (cognitive skills) }\end{array}$ & $\begin{array}{l}\text { Successful } \\
\text { intervention for most } \\
\text { participants and } \\
\text { opportunity to } \\
\text { participate in the } \\
\text { general classroom's } \\
\text { activities. Less } \\
\text { positive results for } \\
\text { younger participants }\end{array}$ \\
\hline $\begin{array}{c}\text { Lindsay \& } \\
\text { Hounsell (2017) }\end{array}$ & $\begin{array}{c}\text { Motor } \\
\text { impairment or } \\
\text { developmental } \\
\text { disabilities }\end{array}$ & 18 & $6-13$ years & $\begin{array}{c}\text { LEGO@ } \\
\text { Education } \\
\text { Mindstorm } \\
\text { s }\end{array}$ & $\begin{array}{l}\text { Classroom } \\
\text { inside a } \\
\text { pediatric } \\
\text { hospital }\end{array}$ & $\begin{array}{l}\text { Assessment of the } \\
\text { effectiveness of } \\
\text { robots in STEM } \\
\text { education for } \\
\text { students with } \\
\text { disabilities } \\
\text { (cognitive skills) }\end{array}$ & $\begin{array}{l}\text { After the adaptation of } \\
\text { the program to the } \\
\text { children's needs, } \\
\text { increased participation } \\
\text { and enhancement of } \\
\text { their cognitive skills } \\
\text { was observed }\end{array}$ \\
\hline $\begin{array}{c}\text { Van den } \\
\text { Heuvel et al. } \\
(2017 \mathbf{a})\end{array}$ & $\begin{array}{l}\text { Cerebral palsy } \\
\text { or acquired } \\
\text { brain damage } \\
\text { resulting in } \\
\text { motor } \\
\text { impairment }\end{array}$ & 11 & $\begin{array}{l}1 ; 5-19 \text { years } \\
\text { (mental age: } \\
1 ; 5-8 \text { years) }\end{array}$ & IROMEC & $\begin{array}{l}\text { Special } \\
\text { education } \\
\text { school/ } \\
\text { rehabilitation } \\
\text { center }\end{array}$ & $\begin{array}{l}\text { Assessment of the } \\
\text { robot's ability to } \\
\text { enhance play } \\
\text { skills (social } \\
\text { skills) }\end{array}$ & $\begin{array}{l}\text { Positive results but } \\
\text { researchers suggest } \\
\text { that the robotic tool } \\
\text { can be adjusted in } \\
\text { order to support play } \\
\text { for children with } \\
\text { motor impairment }\end{array}$ \\
\hline $\begin{array}{c}\text { Van den } \\
\text { Heuvel et al. } \\
(2017 \mathrm{~b})\end{array}$ & $\begin{array}{l}\text { Cerebral palsy } \\
\text { or acquired } \\
\text { brain damage } \\
\text { resulting in } \\
\text { motor } \\
\text { impairment }\end{array}$ & 17 & $\begin{array}{c}\text { 2-18 years } \\
\text { (mental age: } 2-4 \\
\text { years) }\end{array}$ & ZORA & $\begin{array}{l}\text { Special } \\
\text { education } \\
\text { school/ } \\
\text { rehabilitation } \\
\text { center }\end{array}$ & $\begin{array}{l}\text { Assessment of the } \\
\text { robot's ability to } \\
\text { enhance their } \\
\text { cognitive, motor, } \\
\text { and } \\
\text { communication } \\
\text { skills (social, } \\
\text { cognitive, and } \\
\text { functional skills) }\end{array}$ & $\begin{array}{l}\text { Positive results after } \\
\text { the implementation of } \\
\text { the robotic partner in } \\
\text { the enhancement of } \\
\text { motor, cognitive, and } \\
\text { social skills }\end{array}$ \\
\hline $\begin{array}{c}\text { Albo-Canals et } \\
\text { al. (2018) }\end{array}$ & $\begin{array}{l}\text { ASD and } \\
\text { cognitive } \\
\text { impairments }\end{array}$ & 12 & $6-14$ years & KIBO & $\begin{array}{l}\text { General } \\
\text { education } \\
\text { school }\end{array}$ & $\begin{array}{l}\text { Evaluation of the } \\
\text { participation rate } \\
\text { of children in } \\
\text { activities with the } \\
\text { robot, of the }\end{array}$ & $\begin{array}{l}\text { Positive results in } \\
\text { most areas }\end{array}$ \\
\hline
\end{tabular}




\begin{tabular}{|c|c|c|c|c|c|c|c|}
\hline & & & & & & $\begin{array}{l}\text { development of } \\
\text { their social skills, } \\
\text { of their } \\
\text { comprehension of } \\
\text { the way it is used, } \\
\text { of the ability to } \\
\text { participate in the } \\
\text { robot's coding, } \\
\text { and of the } \\
\text { comprehension of } \\
\text { cause-effect } \\
\text { (social and } \\
\text { cognitive skills) }\end{array}$ & \\
\hline $\begin{array}{l}\text { Bargagna et al. } \\
\text { (2019) }\end{array}$ & Down syndrome & 8 & $8 ; 5$ years (mean) & Bee-Bot & Robotics lab & $\begin{array}{l}\text { Assessment of the } \\
\text { robot's ability to } \\
\text { enhance the } \\
\text { executive skills of } \\
\text { children with } \\
\text { Down syndrome } \\
\text { (social and } \\
\text { cognitive skills) }\end{array}$ & $\begin{array}{l}\text { Great heterogeneity in } \\
\text { the study's results and } \\
\text { presentation of } \\
\text { qualitative data only } \\
\text { for two participants. } \\
\text { Improvement of } \\
\text { executive skills only } \\
\text { for one participant. } \\
\text { Positive results } \\
\text { relevant to } \\
\text { engagement, interest, } \\
\text { and interaction }\end{array}$ \\
\hline $\begin{array}{l}\text { Culén et al. } \\
\text { (2019) }\end{array}$ & $\begin{array}{c}\text { Myalgic } \\
\text { encephalomyelit } \\
\text { is }\end{array}$ & 9 & $12-16$ years & AV1 & $\begin{array}{l}\text { General } \\
\text { education } \\
\text { school }\end{array}$ & $\begin{array}{l}\text { Implementation of } \\
\text { the robot for the } \\
\text { enhancement of } \\
\text { emotions of } \\
\text { relatedness and } \\
\text { empathy in } \\
\text { adolescents with } \\
\text { disabilities (social } \\
\text { skills) }\end{array}$ & $\begin{array}{l}\text { Positive results for } \\
\text { most participants }\end{array}$ \\
\hline $\begin{array}{l}\text { Khaksar et al. } \\
\qquad(2020)\end{array}$ & $\begin{array}{l}\text { Intellectual } \\
\text { disability, } \\
\text { speech-language } \\
\text { impairment, } \\
\text { sensory } \\
\text { disability }\end{array}$ & $15-20$ & $\begin{array}{l}\text { 5-10 years }\left(1^{\text {st }}\right. \\
\text { team }) \\
10-15 \text { years }\left(2^{\text {nd }}\right. \\
\text { team }) \\
\text { 16-18 years }\left(3^{\text {rd }}\right. \\
\text { team })\end{array}$ & Matilda & $\begin{array}{l}\text { Special } \\
\text { education } \\
\text { school }\end{array}$ & $\begin{array}{l}\text { Assessment of the } \\
\text { role of robotic } \\
\text { tools in the } \\
\text { education of } \\
\text { children with } \\
\text { disabilities in } \\
\text { special schools } \\
\text { and of the factors } \\
\text { that contribute to } \\
\text { their successful } \\
\text { implementation } \\
\text { (social and } \\
\text { cognitive skills) }\end{array}$ & $\begin{array}{l}\text { After listing the } \\
\text { results of the } \\
\text { interventions with the } \\
\text { robot and of the } \\
\text { interviews with the } \\
\text { educators, } 18 \text { factors } \\
\text { that should be taken } \\
\text { into consideration } \\
\text { when designing } \\
\text { robotic tools were } \\
\text { found. Additionally, } \\
\text { the results from the } \\
\text { interaction with the } \\
\text { robot were positive } \\
\text { regarding the social } \\
\text { and cognitive skills of } \\
\text { students }\end{array}$ \\
\hline $\begin{array}{c}\text { Van den } \\
\text { Heuvel et al. } \\
\quad(2020)\end{array}$ & $\begin{array}{l}\text { Severe motor } \\
\text { impairment }\end{array}$ & 33 & $3-18$ years & ZORA & $\begin{array}{l}\text { Rehabilitation } \\
\text { centers and } \\
\text { special } \\
\text { education } \\
\text { school }\end{array}$ & $\begin{array}{l}\text { Evaluation of the } \\
\text { effectiveness of } \\
\text { the robot in the } \\
\text { education and } \\
\text { rehabilitation of } \\
\text { children with } \\
\text { severe motor } \\
\text { impairment and of } \\
\text { the roles of the } \\
\text { robotic partner } \\
\text { (social and } \\
\text { functional skills) }\end{array}$ & $\begin{array}{l}\text { Positive results in the } \\
\text { enhancement of social } \\
\text { skills, of play, and } \\
\text { motor functions. } \\
\text { Assignment of roles to } \\
\text { the robotic partner }\end{array}$ \\
\hline
\end{tabular}

Source: Authors. 


\section{Results}

The research papers that were chosen for analysis for this review were regarding the use of educational robotics for children and adolescents with disabilities and the participants' ages were between 1;5 and 19 years. As it is summarized in Table 1, the participants were children and adolescents with Autism Spectrum Disorders, Down Syndrome, speech-language disorder, intellectual disability, motor impairment, cerebral palsy, sensory disabilities, and other impairments. It is apparent that there is heterogeneity among these groups of participants (even between children who have the same syndrome) in terms of their characteristics, their needs, and their capabilities. Therefore, the analysis of results was conducted based on those skills that were acquired or enhanced after interventions with robotic tools took place.

After taking into account the eligibility criteria that were set previously, the authors decided that 12 research articles met the requirements in order to be included in the review. Most interventions were aiming towards enhancing social skills (10 research articles), some of them were focused on increasing cognitive skills (6 research articles), and some others were about functional skills ( 3 research articles). It should be noted that in most cases, a combination of target skills was made and this is how the previous categorization of skills emerged. That being said, some research articles combined social, cognitive, and functional skills as their main targets.

In the research by Lee et al. (2015) the robot "iRobiQ" was used for a small group of children with different types of disabilities and with an average age of 4;8 years. This humanoid robot is being used by speech-language therapists, as it has a speech mode and is equipped with a touch screen that allows interaction. Also, due to the way it's designed, it has the ability to narrate stories and respond to the student's actions, making interactions more natural and less "robotic". The data that came from the interviews of three speech-language therapists were mainly positive, as most of them considered the robot and the software to be suitable for speech therapy and noticed maintenance of results regarding the enhancement of communication for the participants. In some cases, they observed that the participants showed affection towards the robot (e.g. "I love you", "let's play together", etc.).

In the research by Shamsuddin et al. (2015) the popular humanoid robot "Nao" was used for 12 school-aged children with ASD. The results showed that 10 out of 12 children exhibited positive behaviors towards the robot, increased communication and therefore, their autistic traits and behaviors were minimized. However, it is worthwhile to note that those results were regarding the children's first interaction with the robot and it is assumed that repeated exposure could possibly induce different outcomes.

The research by Bonarini et al. (2016) was divided into two parts, and the first intervention was made for three 3 -yearold children with ASD, and the second was made for 8 children between the ages of 6 and 10 years old with various types of disabilities (ASD, intellectual disability, Down syndrome, Prader-Willy syndrome, and psychosis). The "Teo" robot, which is a mobile robot, was used for both parts of the interventions. For the first part of the research, where participants were fewer in number, many variations appeared in the results, which can be attributed to the heterogeneity of characteristics that children with autism exhibit. However, researchers considered the results to be mainly positive regarding several communication parameters (verbal/ non-verbal communication, manifestation of interest towards novel stimuli, and positive emotions). In the second part, where more students participated, there was still diversity in the results. In any case, the research group indicated mostly positive results for the participants after the interventions, and more specifically in the areas of communication, expression of personal needs, the manifestation of positive emotions, and social play. Moreover, an evaluation was made in order to assess the effectiveness of the robot in terms of enhancing the children's functional skills and the results were positive.

The study by Encarnação et al. (2017) was one of the few research papers that were more about the inclusion of children with disabilities in general schools. The robotic kit "Lego Mindstorms NXT" was used, combined with an Augmentative and Alternative Communication application for 9 children with motor impairment and speech-language 
disorder. Additionally, 9 special and 9 general education teachers participated in the study. The curricular subjects that were related to this study were Language, Math, Science, and Social studies. The results showed some difficulties in the execution of some activities and in the interaction with the robotic tool. This was attributed to the participants' young age, as the intervention system that was used (robot-AAC application-eye tracking device) could be considered quite complex and demanding. The evaluation of results was based on the impact of the robotic system on the quality of the learning process and not on the process of acquiring new skills, and they were positive. The educators that participated stated that the robotic partner assisted some students to gain access to the general curriculum and its activities. Less positive results were reported for two younger participants (aged 3 years old).

Just like the aforementioned research group focused on cognitive areas, Lindsay \& Hounsell (2017) used the robotic kit «LEGO MINDSTORMS /EV3» and their aim was to enhance the cognitive skills of 18 school-aged children. The students were diagnosed with motor impairment or developmental disabilities. The areas that were covered were those included in "STEM" education, which are Science, Technology, Engineering, and Mathematics. The interventions were made in a classroom inside a pediatric clinic. The clinic personnel and the children's parents reported that some adjustments to the educational program were made in order to support their participation in the program and to overcome some impediments. The results showed that those adjustments rendered the program effective and suitable for the children's educational, cognitive, physical, and communicational needs.

Two interventions were made by Van den Heuvel et al. (2017a \& 2017b) for participants with similar characteristics (cerebral palsy or acquired brain injury resulting in physical disability). The participants were children and adolescents between the ages of 1;5 and 19 years old. The first intervention employed the "IROMEC" robot, which is a machine-like robot, but it is equipped with a "face". The main parameter of this research was to assess the effectiveness of this robotic platform in increasing the social skills of the participants, and more specifically, their play skills. Results showed that although the intervention had a positive impact on the children's play skills, some adjustments to the robotic tool would be necessary in order to surpass some technical difficulties in the future.

The other research (Van den Heuvel et al., 2017b) brought into service the "ZORA" robot, which resembles the humanoid robot "Nao". The only difference between the two is that "ZORA" operates with the help of a different software program, which is altering its functions and capabilities. This study aimed to enhance the social, cognitive, and functional skills of children with disabilities and the results were positive. Along with other findings, the specialists mentioned that this robot is able to boost students' play skills, their motivation, their concentration, and their way of taking initiative.

The "KIBO" robot was the main intervention tool in the research by Albo-Canals et al. (2018). This robotic tool is not equipped with a screen and it is suitable for children between the ages of 4-7 years. Additionally, it includes some programming "bricks", each one of which has the ability to alter the robot's functions. The research team set the intervention's goals, which were mainly about examining the effectiveness of the robot in encouraging social behaviors and expression of emotions towards peers and adults and also in understanding the concept of cause and effect that accompanies its use. Therefore, the goals of the intervention were about the social and cognitive skills of children with ASD and cognitive disabilities that participated. Results indicated that most children exhibited interest towards the robotic partner, understood its function (although some discrepancies emerged), and manifested social behaviors more towards adults than with their peers. Also, the conception of cause and effect that was linked with the operation of the robot was not possible for only one participant.

Bargagna et al. (2019) used the zoomorphic robot "Bee-Bot" in interventions for 8 children with Down syndrome and a mean age of 8;5 years. Sessions were carried out in a robotics lab and were aiming towards increasing the participants' social and cognitive skills. More specifically, the researchers focused on amplifying their executive functions and investigated the 
effectiveness of the intervention in other skills as well. Of particular interest is the fact that although 8 children participated in this study, analysis of results was made only for two of them, due to the heterogeneity of findings. Results revealed that for one of those two participants executive functions were improved, but both exhibited increased interest, attention, and social interactions with peers and adults.

The research by Culén et al. (2019) was involving adolescents with myalgic encephalomyelitis. This is a syndrome that affects, among other things, the ability to interact with other people, as those who have it should live away from crowds. The "AV1" robot, which was the main intervention tool for this study, is a robotic platform that differs from those mentioned earlier, as it is categorized as a telepresence robot. This means that this robot allows people who cannot attend social occasions or other activities to have remote and easy access instantly. The effectiveness of this robotic partner in enhancing "relatedness" (as was mentioned in the research paper) for adolescents who weren't able to attend school or participate in other activities was assessed. Results were mainly positive, as the 9 participating adolescents exhibited increased social interactions. Specifically, the intervention allowed them to experience relatedness with other people, participate in everyday activities and be more productive.

The humanoid robot "Matilda" was used by the research team of Khaksar et al. (2020) for 15 to 20 children and adolescents between the ages of 5 and 18 years with various types of disabilities (intellectual disability, speech-language disorder, and sensory disabilities). This study aimed to examine the efficacy of the "Matilda" robot in amplifying the social and cognitive skills of children and adolescents that attended special education schools, and the analysis of those factors that must be taken into account when using educational robotic tools. Participants were divided into three groups according to their age and the findings that were about their social and cognitive skills were mainly positive. Worthy of mention were the factors and conditions that were noted by the research team and affect the successful application of educational robotics in special education. Some of them are the appearance and characteristics of a robot, the students' prior experience, a robot's accessibility, the correlation with the school's curriculum, etc.

Lastly, a more recent study by Van den Heuvel et al. (2020) where the robot "ZORA" was used again (see Van den Heuvel et al., 2017b) for children with severe motor disabilities, was aiming to assess the influence of the robot to their social and functional skills. In particular, the objective of the study was to assess whether the robot would be an effective mediator in the education and rehabilitation of children with severe motor disabilities and to determine the roles that are assigned to the robotic partner. This study had a large sample (33 children and adolescents aged between 3 and 18 years) and was conducted in two rehabilitation centers and a special education school. Results suggest that the social interactions of the participants were improved, as well as their play skills. In the area of functional skills, there were improvements regarding the participants' mobility functions. Besides, the humanoid robot was assigned with duties during intervention sessions, like guiding, rewarding, and motivating the participants.

\section{Discussion}

In this section, the authors will attempt to answer the research questions that were set in the beginning and make additional remarks. The first research question was whether the use of educational robotics can enhance the social skills of children with disabilities. From the analysis of results, it can be observed that educational robotics is a contemporary, appealing, and effective way of developing various types of social skills for children with different types of disabilities or special educational needs. For instance, it was evident that there were successful interventions using robots for children with autism spectrum disorders, Down syndrome, intellectual disability, speech-language disorders, motor disabilities, cerebral palsy, etc. 
The second research question was whether the use of educational robotics can enhance the cognitive skills of children with disabilities. From the analysis that was conducted it was apparent that in most cases, the use of robots could promote and cultivate the cognitive skills of children. For instance, in two research papers, it was evident that there was easier access to the school curriculum for the participants of the interventions. It is notable that the participants of these two interventions were children with motor disabilities, speech-language disorders, ASD, and cognitive impairments and were of different age groups (3 to 6 and 6 to 14 years).

Interestingly enough, most articles were mainly focused on the development of social skills for children and adolescents with disabilities, which in fact facilitates and promotes their successful inclusion in school and society in general. This way the third research question is being answered, which is about the skills that are of particular interest for researchers and are reinforcing inclusion. The improvement of communication, verbal or non-verbal, of play skills, engagement, participation in group activities, and empathy are some examples of social skills that could be enhanced through robotic education.

The fourth research question, which is the last of this review, was whether educational robotics can promote successful inclusion for children with disabilities. The enhancement of social, cognitive, and functional skills of students with disabilities and special educational needs is considered to be necessary in order to achieve their successful inclusion in the educational system, which was achieved according to most research papers that were included for analysis in this review. It should be noted that in most cases, some adjustments should be made for the robotic tools and/or for the classroom activities to achieve the best results for each student.

There were only a few research articles that focused on the training of the rest participating students as well. Therefore, future research groups that implement educational robotic tools for children and adolescents with disabilities should take into account those factors that help educators and their peers to actively participate in their inclusive training. It is deemed necessary to include all classroom members as participants (if the intervention is taking place in a classroom) and also to carry out more targeted interventions that will not only be focused on the development of social or cognitive skills but will also report the success rate of the method in the inclusion of students.

One inherent limitation of interventions that implement robotic tools is the requirement for a second educator in the classroom who should be assigned the role of "operator" of the robot. In addition, the educator must help the student in their activities with the robotic partner, thus working as their assistant. Those tasks cannot be carried out by the main teacher, due to the large number of children that attend the classroom of a general education school, therefore emerges the need for a second teacher. Additionally, in order for inclusion to be successful educators should work on their time management skills, as students with disabilities usually need more time to complete classroom activities as compared to their typically developing peers (Encarnação et al., 2017).

\section{Conclusion}

In summary, it is noteworthy to mention that educational robotics is a very promising method that can promote inclusive education for children with disabilities and special educational needs through the enhancement of their social, cognitive, and functional skills. Educational robotics, though, should be implemented after careful design according to the students' needs and only after evaluating all those factors that are related to the robotic partner's specificities. In any case, both educators and therapists should take into account the heterogeneity of children and adolescents with disabilities in terms of their capabilities and characteristics to implement successful interventions.

Future literature reviews could include additional eligible studies for analysis, and those studies should involve even 
greater sample sizes. Generalization and maintenance measures are variables that could possibly be of importance when interpreting the studies' results and they could be included for comparison and analysis of the selected research papers. Additionally, a meta-analysis of the data could be a better indicator of the robotic tools' success rate for the inclusion of children and adolescents with disabilities. Finally, research teams and therapists should consider adapting such intervention programs for other age groups as well, and especially for adults with disabilities who face difficulties in their participation to certain activities and their inclusion in society in general.

\section{References}

Albo-Canals, J., Martelo, A. B., Relkin, E., Hannon, D., Heerink, M., Heinemann, M., Leidl, K., \& Bers, M. U. (2018). A Pilot Study of the KIBO Robot in Children with Severe ASD. International Journal of Social Robotics, 10(3), 371-383. https://doi.org/10.1007/s12369-018-0479-2

Alston, R. J., \& Hampton, J. L. (2000). Science and engineering as viable career choices for students with disabilities: A survey of parents and teachers. Rehabilitation Counseling Bulletin, 43, 158-164.

*Bargagna, S., Castro, E., Cecchi, F., Cioni, G., Dario, P., Dell’Omo, M., Di Lieto, M. C., Inguaggiato, E., Martinelli, A., Pecini, C., \& Sgandurra, G. (2019). Educational Robotics in Down Syndrome: A Feasibility Study. Technology, Knowledge and Learning, 24(2), 315-323. https://doi.org/10.1007/s10758-0189366-z

Barrow, L., Markman, L., \& Rouse, C. E. (2009). Technology's edge: The educational benefits of computer-aided instruction. American Economic Journal: Economic Policy, 1(1), 52-74.

* Bonarini, A., Clasadonte, F., Garzotto, F., Gelsomini, M., \& Romero, M. (2016, December). Playful interaction with Teo, a mobile robot for children with neurodevelopmental disorders. In Proceedings of the 7th International Conference on Software Development and Technologies for Enhancing Accessibility and Fighting Info-exclusion (pp. 223-231).

* Culén, A. L., Børsting, J., \& Odom, W. (2019, June). Mediating relatedness for adolescents with ME: Reducing isolation through minimal interactions with a Robot Avatar. In Proceedings of the 2019 on Designing Interactive Systems Conference (pp. 359-371).

Diamond, A. (2013). Executive functions. Annual Review of Psychology, 64, 135-168.

*Disseler, S., \& Mirand, G. (2017). Students with Disabilities and LEGO@ Education. Journal of Education and Human Development, 6(3), 38-52. https://doi.org/10.15640/jehd.v6n3a5

*Encarnação, P., Leite, T., Nunes, C., Nunes da Ponte, M., Adams, K., Cook, A., Caiado, A., Pereira, J., Piedade, G., \& Ribeiro, M. (2017). Using assistive robots to promote inclusive education. Disability and Rehabilitation: Assistive Technology, 12(4), 352-372. https://doi.org/10.3109/17483107.2016.1167970

Francisco, M. P. B., Hartman, M., \& Wang, Y. (2020). Inclusion and Special Education. Education Sciences, $10(9), 238$.

Johnson, D. W., \& Johnson, R. T. (1994). Learning together and alone. Cooperative, competitive, and individualistic learning. Allyn and Bacon.

Jung, S. E., Lee, K., Cherniak, S., \& Cho, E. (2020). Non-sequential Learning in a Robotics Class: Insights from the Engagement of a Child with Autism Spectrum Disorder. Technology, Knowledge and Learning, 25(1), 63-81. https://doi.org/10.1007/s10758-018-9394-8

Khaksar, S. M. S., Slade, B., Wallace, J., \& Gurinder, K. (2020). Critical success factors for application of social robots in special developmental schools: Development, adoption and implementation. International Journal of Educational Management, 34(4), 677-696. https://doi.org/10.1108/IJEM-08-2019-0304

Khan, K. S., Kunz, R., Kleijnen, J., \& Antes, G. (2003). Five steps to conducting a systematic review. Journal of the Royal Society of Medicine, 96, 118-121.

Lee, H., \& Hyun, E. (2015). The intelligent robot contents for children with speech-language disorder. Educational Technology and Society, 18(3), 100-113.

Leroux, P. (1999). Educational Robotics. International Journal of Artificial Intelligence in Education, 10, 1080-1089.

Lindsay, S. (2020). Exploring Skills Gained Through a Robotics Program for Youth With Disabilities. OTJR Occupation, Participation and Health, 40(1), 5763. https://doi.org/10.1177/1539449219868276

Lindsay, S., \& Hounsell, K. G. (2017). Adapting a robotics program to enhance participation and interest in STEM among children with disabilities: a pilot study. Disability and Rehabilitation: Assistive Technology, 12(7), 694-704. https://doi.org/10.1080/17483107.2016.1229047

Pihlainen, K., Suero Montero, C., \& Kärnä, E. (2017). Fostering parental co-development of technology for children with special needs informal learning activities. International Journal of Child-Computer Interaction, 11, 19-27. https://doi.org/10.1016/j.ijcci.2016.10.010

Rodriguez, C. C., \& Garro-Gil, N. (2015). Inclusion and integration on special education. Procedia-Social and Behavioral Sciences, $191,1323-1327$.

Shamsuddin, S., Yussof, H., Hanapiah, F. A., Mohamed, S., Jamil, N. F. F., \& Yunus, F. W. (2015, August). Robot-assisted learning for communication-care in autism intervention. In 2015 IEEE International Conference on Rehabilitation Robotics (ICORR) (pp. 822-827).

Van Den Heuvel, R. J. F., Lexis, M. A. S., \& De Witte, L. P. (2017a). Can the IROMEC robot support play in children with severe physical disabilities? A pilot study. International Journal of Rehabilitation Research, 40(1), 53-59. https://doi.org/10.1097/MRR.0000000000000200 
Research, Society and Development, v. 10, n. 9, e36210918238, 2021

(CC BY 4.0) | ISSN 2525-3409 | DOI: http://dx.doi.org/10.33448/rsd-v10i9.18238

Van Den Heuvel, R. J. F., Lexis, M. A. S., \& De Witte, L. P. (2017b). Robot ZORA in rehabilitation and special education for children with severe physical disabilities: A pilot study. International Journal of Rehabilitation Research, 40(4), 353-359. https://doi.org/10.1097/MRR.0000000000000248

Van den Heuvel, R. J. F., Lexis, M. A. S., \& de Witte, L. P. (2020). ZORA Robot Based Interventions to Achieve Therapeutic and Educational Goals in Children with Severe Physical Disabilities. International Journal of Social Robotics, 12(2), 493-504. https://doi.org/10.1007/s12369-019-00578-z 